\title{
УДК 657
}

DOI: https://doi.org/10.32782/2304-0920/5-78-23

Височан О. С.

Литвиненко Н. О.

Національний університет «Львівська політехніка»

\section{ПРОБАЕМАТИКА АНААІТИЧНОГО ОПРАЦЮВАННЯ ОБАІКОВИХ ААНИХ ЩОАО ААМІНІСТРАТИВНИХ ВИТРАТ ПІАПРИЕМСТВА}

\begin{abstract}
Досліджено потенційну можливість підвищення корисності аналітичного обліку як підгрунтя для зростання ефективності аналізу адміністративних витрат в управлінні фінансово-господарською діяльністю підприємства. Здійснено критичну оцінку встановлення критерія мінімізації як основної мети управління адміністративними витратами на підприємстві. Проведено структуризацію завдань аналізу адміністративних витрат. Виокремлено проблеми, які виникають під час застосування класичних прийомів для аналізу адміністративних витрат підприємства, а також установлено можливі негативні наслідки такого застосування на практиці. Запропоновано номенклатуру субрахунків до рахунку бухгалтерського обліку «Адміністративні витрати». Встановлено можливість застосування технології АВС-аналізу для побудови аналітичного обліку адміністративних витрат.

Ключові слова: адміністративні витрати, непрямі витрати, АВС-аналіз, аналітичний облік, субрахунок.
\end{abstract}

Постановка проблеми. Адміністративні витрати є чи не найбільш різнорідною за своїм економічним змістом категорією витрат, які пов'язані із забезпеченням процесу управління на підприємстві. Така різнорідність створюе проблеми для їх первинної ідентифікації та структуризації з метою подальшого аналізу та оптимізації.

На практиці аналіз адміністративних витрат часто не відповідає запитам управління, оскільки зазвичай сконцентрований на двох аспектах:

1) адміністративні витрати розглядаються як складова частина непрямих, що ще більш урізноманітнює структуру останніх;

2) сам аналіз використовується як допоміжний інструмент для встановлення найбільш ефективного методу розподілу непрямих витрат - завдання, вирішення якого часто носить винятково маніпулятивний характер.

Водночас проблема встановлення оптимальної величини адміністративних витрат для конкретного підприємства залишається невирішуваною. Ускладнює ситуацію те, що у грунтовному аналізі адміністративних витрат буває незацікавлене саме керівництво суб'єкта господарювання через існування ризиків, пов'язаних із можливим виявленням необгрунтовано високих сум нарахованої заробітної плати, особливо премій управлінському персоналу.

Аналіз останніх досліджень i публікацій. У більшості сучасних публікацій учені-економісти розглядають адміністративні витрати співвідносно 3 непрямими, тоді як їх аналіз - як функцію управління господарським процесом на підприємстві. Внесок у розв'язання проблем, пов'язаних 3 аналізом адміністративних витрат як окремої статті чи у складі непрямих/комплексних витрат, здійснили: Г.Ф. Азаренков, О.М. Загородна, В.В. Іванієнко, М.І. Ковальчук, Є.В. Мних, В.І. Отенко, Г.В. Савицька, B.M. Серединська, Р.В. Федорович та інші вітчизняні науковці.

Завершених робіт, які б містили грунтовні дослідження особливостей аналізу адміністративних витрат як окремого складника витрат діяльності підприємства, все ще бракує.

Виділення не вирішених раніше частин загальної проблеми. Проблематика аналізу адміністративних витрат тісно пов'язана із завданням удосконалення аналітичного опрацювання облікових даних стосовно цієї категорії витрат.
Мета статті. Головною метою цієї роботи $є$ дослідження потенціалу корисності аналітичного обліку як підгрунтя для підвищення ефективності аналізу адміністративних витрат в управлінні фінансово-господарською діяльністю підприємства. Мета диктує необхідність послідовного вирішення таких основних завдань:

- дослідження можливості встановлення критерія мінімізації як основної мети управління адміністративними витратами на підприємстві;

- структуризація завдань аналізу адміністративних витрат;

- виокремлення проблем, які виникають під час застосування класичних прийомів для аналізу адміністративних витрат підприємства, а також дослідження можливих негативних наслідків такого застосування на практиці;

- розроблення можливої номенклатури субрахунків до рахунку бухгалтерського обліку «Адміністративні витрати»;

- встановлення можливості застосування технології АВС-аналізу для побудови аналітичного обліку адміністративних витрат.

Виклад основного матеріалу. У науковій літературі [1-6] базовими етапами проведення економічного аналізу на підприємстві є: підготовчий (роботи організаційного характеру), основний (безпосередньо аналітичні роботи) та завершальний (узагальнення й оформлення результатів аналізу). На кожному із цих етапів виокремлюють підетапи; реалізація їх у сучасних умовах супроводжується виникненням проблем організаційно-методичного характеру, вирішення яких є надважливим завданням для підвищення результативності аналізу на всіх його ділянках, у тому числі під час дослідження адміністративних витрат.

У спеціалізованих фахових джерелах першим підетапом підготовчого етапу проведення аналізу виокремлюють встановлення мети, другим - вибір об'єктів. Уважаємо, що розділяти ці етапи недоцільно, оскільки об'єкти аналізу визначаються його метою, що становить єдиний сектор аналітичних робіт.

У практиці економічного аналізу вважається, що основною метою управління адміністративними витратами є мінімізація їх загальної величини та зниження тенденції зміни останньої впродовж наступного після проведення аналізу періоду часу. Водночас, на нашу думку, використання засобів, орієнтованих виключно на зниження адмі- 
ністративних витрат, без грунтовного дослідження можливих наслідків, є неприпустимим (табл. 1).

У теорії критерій мінімізації як прагнення досягнути мінімуму витрат за наявних обмежень замінюють критерієм оптимізації - прагнення досягнути оптимальної величини витрат (iї значення не завжди мінімально можливе) за наперед заданими параметрами. У разі управління адміністративними витратами параметри оптимізації далеко не очевидні й часто є предметом суб'єктивних суджень менеджера. Зростання витрат упродовж певного часу $є$ не завжди негативним явищем, тоді як їх зниження - ще не свідчення поліпшення господарської діяльності підприємства. Це ускладнює встановлення кінцевої мети аналізу адміністративних витрат.

Побутує думка, що оптимальну величину витрат, а також тенденції їх зміни, які можна віднести до позитивних, слід зіставляти 3 іншими показниками фінансово-господарської діяльності, наприклад виробничими витратами чи прибутком. Логіка та, що зростання обсягів реалізації та прибутковості є свідченням ефективності роботи управлінського апарату, тому збільшення витрат на забезпечення останнього є об'єктивним, i навпаки. Однак, як показує практика, на етапі зростання, впровадження нових видів продукції, реорганізації підприємства темпи зростання адміністративних витрат часто перевищують аналогічний показник по виробничих витратах чи прибутку. Надлишкові витрати загальногосподарського характеру планується компенсувати додатковим прибутком у майбутньому. Рішення про їх зменшення може виявитися хибним. Окрім того, це призводить до негативної практики встановлення планової величини адміністративних витрат у бюджеті підприємства як фіксованого відсотку від обсягу виробничих витрат. Важли- вим є не стільки адекватне зростання адміністративних витрат, скільки можливість підприємства його профінансувати.

Загалом порівняння різних за своїм змістом величин виявляється проблемою навіть на етапі структурного аналізу адміністративних витрат через їх економічну неоднорідність. Зіставлення витрат на оплату праці адміністративного персоналу, представницьких витрат, витрат, пов'язаних з оплатою отриманих консультаційно-інформаційних послуг, та інших категорій через важкість моделювання оптимального їх співвідношення звужує функціонал аналізу до довідкового.

На нашу думку, мета аналізу адміністративних витрат повинна формуватися виходячи 3 двох базових принципів:

1) проблеми у діяльності підприємства не вирішуються виключно завдяки зменшенню адміністративних витрат, тоді як їх оптимізація у сучасному динамічному середовищі залишається невирішуваним завданням;

2) аналіз витрат повинен здійснюватися не автономно, а в комплексі $з$ аналізом джерел їх фінансування.

3 урахуванням викладеного загальна мета аналізу адміністративних витрат може бути сформульована як виявлення поточних та потенційних проблем у фінансуванні й освоєнні ресурсів на адміністративно-управлінські потреби.

Мета деталізується у завданнях аналізу адміністративних витрат, перелік яких може бути доволі широкий:

- виявлення найбільш витратомістких ланок у забезпеченні загальногосподарської діяльності підприємства;

- забезпечення аналітичною інформацією підсистеми контролю ефективності використання ресурсів на загальногосподарські потреби;

Таблиця 1

Потенційні загрози управлінню адміністративними витратами на основі критерія мінімізації

\begin{tabular}{|c|c|c|}
\hline Напрями & Стандартні способи & Можливі негативні наслідки \\
\hline $\begin{array}{c}\text { Зниження витрат на } \\
\text { утримання основних } \\
\text { засобів, інших матеріальних } \\
\text { необоротних активів } \\
\text { загальногосподарського } \\
\text { використання } \\
\end{array}$ & $\begin{array}{c}\text { Зниження витрат на опалення, освітлення, } \\
\text { водопостачання; скорочення площ, взятих } \\
\text { в операційну оренду під офіси; скорочення } \\
\text { службового автопарку }\end{array}$ & $\begin{array}{c}\text { Зниження ергономічності робочих місць } \\
\text { та комфортності праці і, як наслідок, } \\
\text { їі продуктивності. Виникнення ризиків } \\
\text { порушення санітарно-гігієнічних норм }\end{array}$ \\
\hline $\begin{array}{c}\text { Зниження витрат на } \\
\text { персонал }\end{array}$ & $\begin{array}{c}\text { Пошук методів нематеріального } \\
\text { стимулювання працівників, зменшення } \\
\text { преміального фонду, наймання працівників } \\
\text { на умовах аутсорсингу } \\
\end{array}$ & $\begin{array}{c}\text { Ризики втрати конфіденційної інформації, } \\
\text { зниження рівня лояльності працівників, } \\
\text { виникнення випадків саботажу та інших } \\
\text { негативних явищ } \\
\end{array}$ \\
\hline $\begin{array}{c}\text { Зниження витрат на } \\
\text { службові відрядження } \\
\text { управлінців підприємства }\end{array}$ & $\begin{array}{l}\text { Виявлення та недопущення відряджень, в } \\
\text { яких немає об’єктивної необхідності для } \\
\text { підприємства (напр., перенесення ділових } \\
\text { зустрічей у формат Skуре-конференцій); } \\
\text { встановлення обмежень на витрачання } \\
\text { коштів, які відшкодовуються за рахунок } \\
\text { підприємства (типів транспортних квитків, } \\
\text { готельних номерів для проживання та ін.) }\end{array}$ & $\begin{array}{c}\text { Значний рівень суб’єктивізму під } \\
\text { час оцінки важливості тих чи інших } \\
\text { службових відряджень, унаслідок чого } \\
\text { можуть бути переглянуті відрядження, } \\
\text { які суттєво впливають на розвиток } \\
\text { підприємства }\end{array}$ \\
\hline $\begin{array}{c}\text { Зниження витрат на послуги } \\
\text { сторонніх організацій }\end{array}$ & $\begin{array}{c}\text { Постійний моніторинг ринку професійних } \\
\text { юридичних, аудиторських, консалтингових } \\
\text { та інших послуг для пошуку партнерів } \\
\text { із найбільш привабливими ціновими } \\
\text { пропозиціями }\end{array}$ & $\begin{array}{c}\text { Необхідність залучення сторонніх } \\
\text { організацій у низці випадків встановлена } \\
\text { законодавчо, наприклад обов'язкова } \\
\text { професійна оцінка під час продажу } \\
\text { об’єктів нерухомості та іншого у переходу } \\
\text { прав власності, здійснення обов'язкового } \\
\text { аудиту тощо. Співпраця з організаціями, } \\
\text { які пропонують найнижчу ціну за свої } \\
\text { послуги, може свідчити про низьку якість } \\
\text { останніх }\end{array}$ \\
\hline $\begin{array}{l}\text { Зниження загальних } \\
\text { корпоративних витрат }\end{array}$ & $\begin{array}{c}\text { Зниження непродуктивної категорії } \\
\text { організаційних та представницьких витрат }\end{array}$ & $\begin{array}{c}\text { Зростання ризиків виникнення іміджевих } \\
\text { утрат }\end{array}$ \\
\hline $\begin{array}{c}\text { Зниження податкового } \\
\text { навантаження }\end{array}$ & $\begin{array}{l}\text { Пошук легальних засобів зменшення } \\
\text { обсягів сплачених податків та зборів, } \\
\text { пов’язаних з операційною діяльністю }\end{array}$ & $\begin{array}{c}\text { Збільшення ризиків штрафних санкцій; } \\
\text { більшість важелів зменшення податкового } \\
\text { тиску належить державі }\end{array}$ \\
\hline
\end{tabular}

Джерело: авторська розробка 
- обгрунтування необхідності збільшення/ зменшення фінансування загальногосподарських потреб;

- створення умов для персоніфікації відповідальності за зростання непродуктивних утрат адміністративно-управлінського характеру та ін.

Виходячи з мети та завдань аналізу адміністративних витрат, його об'єктами є: загальна сукупність адміністративних витрат та їхні окремі складники, джерела покриття адміністративних витрат. Залежно від потреб аналізу цей перелік може бути розширено.

На першому етапі організації аналітичних робіт важливим $є$ також установлення періоду проведення аналізу адміністративних витрат. Водночас із сучасним рівнем можливостей автоматизації обліково-аналітичних процесів аналіз адміністративних витрат за необхідності можна проводити щоденно. Зазвичай достатнім уважається місячний або квартальний період, однак за потреби прийняття оперативних рішень аналітичні дані готуються на вимогу за будь-який часовий відтинок. Із тих же причин певним архаїзмом можна вважати виділення окремим етапом розроблення програми з установленням складу учасників, масштабу аналізу, оцінкою наявності ресурсів для його здійснення.

На другому етапі аналізу адміністративних витрат ключовим підетапом є вибір та практичне застосування методичних прийомів для вирішення поставлених завдань (табл. 2).

На підетапі збору й оцінки даних етапу проведення аналітичних робіт суттєвою проблемою для аналізу є низька ступінь використання можливостей облікової системи як потужного джерела аналітичної інформації. Причиною її виникнення є неналежний розвиток аналітичного обліку підприємств, який не відповідає запитам управління.

Під час побудови субрахунків до рахунку «Адміністративні витрати» бухгалтер зазвичай використовує нормативний підхід, в основі якого знаходяться рекомендації, викладені у П(С)БО 16 «Витрати», тоді як бюджет формується 3 виокремленням найбільш значимих для потреб управління статей. Як наслідок, зіставлення фактичних даних бухгалтерського обліку з плановими часто буває утрудненим. Необхідно виконувати низку трансформаційних операцій з укрупнення чи розбивання масивів облікової інформації, що вимагає залучення додаткових ресурсів. Скажімо, відсутність окремої статті «витрати на оплату праці» в номенклатурі статей адміністративних витрат ускладнює підбиття підсумків за цією надважливою категорією витрат, оскільки інформацію про них потрібно виокремлювати зі статей витрат на утримання апарату управління (у частині зарплати працівників адміністративно-управлінського та іншого загальногосподарського персоналу), а також витрат на утримання основних засобів (у частині зарплати працівників охорони). Подібна ситуація спостерігається з елементом витрат «амортизація»: амортизація основних засобів стосується статті, пов'язаної з їх утриманням, тоді як амортизація нематеріальних активів загальногосподарського використання розглядається окремо. У теорії навіть частина суми амортизації основних засобів, які використовувалися під час проведення річних зборів акціонерів (скажімо, інтерактивного мультимедійного комплексу), у бухгалтерському обліку повинні відноситися до загальних корпоративних витрат. Матеріальні витрати «розпорошені» одразу по кількох статтях: загальні корпоративні витрати - матеріальні цінності, які використовуються під час організації корпоративних заходів; витрати на утримання апарату управління - канцелярське та інше приладдя; витрати на утримання основних засобів - матеріали, списані на ремонт; інші витрати загальногосподарського призначення - решта матеріальних витрат.

3 урахуванням цього номенклатура субрахунків, відкритих до рахунку 92 «Адміністративні витрати», може бути такою:

- 921 «Матеріальні адміністративні витрати» суми визнаних витрат матеріалів, палива, енергії, що пов'язані з управлінням та обслуговуванням підприємства;

- 922 «Витрати на оплату праці адміністративно-управлінського та іншого загальногосподарського персоналу» - суми визнаних витрат на виплату основної заробітної плати, додаткової заробітної плати, оплату відпусток та інші витрати на оплату праці адміністративно-управлінського та іншого загальногосподарського персоналу;

- 923 «Відрахування на соціальні заходи в частині адміністративних витрат» - відрахування на загальнообов' язкове державне соціальне та індивідуальне страхування адміністративноуправлінського та іншого загальногосподарського персоналу;

- 924 «Амортизація необоротних активів загальногосподарського призначення» - нараховані амортизаційні відрахування основних засобів, інших необоротних матеріальних активів та нематеріальних активів загальногосподарського призначення;

925 «Витрати, пов’язані 3 отриманням банківських послуг» - плата за розрахунковокасове обслуговування, комісійні банку; витрати, пов'язані з купівлею-продажем валюти;

- 926 «Витрати, пов'язані з отриманням послуг інших сторонніх організацій» - витрати на охоронні, юридичні, інформаційно-консультаційні, аудиторські, телекомунікаційні, транспортні, поштові, профілактичні, ремонтні послуги;

- 927 «Операційні податки» - суми податків та зборів, пов'язаних з операційною діяльністю (крім тих, які відносяться до виробничої собівартості): земельний податок, плата за користування надрами, екологічний податок та ін.;

- 928 «Інші адміністративні витрати» - адміністративні витрати, що не відображаються на інших субрахунках до рахунку 92: придбання (надходження за підпискою) періодичних видань; службові відрядження, орендні платежі тощо.

Звичайно ж, наведений перелік є примірним, і залежно від потреб управління він може розширюватися або, навпаки, скорочуватися. Наприклад, для підприємств, що використовують значний обсяг винайнятих офісних площ та (або) орендовані транспортні засоби для потреб управління, доцільно окремо виділяти субрахунок «Витрати на оренду необоротних активів загальногосподарського призначення». Однак, на нашу думку, надмірна деталізація може призвести до витрачання зайвих ресурсів на дослідження тих категорій адміністративних витрат, які не мають вирішального впливу на управлінські рішення, що в кінцевому підсумку зменшить ефективність проведеного аналізу.

Для визначення конкретного переліку адміністративних витрат, який варто виокремлювати в аналітичному обліку, слід здійснити їх ранжування за параметром значимості для підприємства. Найбільш доцільним для цього, на нашу думку, є 
Таблиця 2

Проблеми у застосуванні класичних прийомів для аналізу адміністративних витрат підприємства

\begin{tabular}{|c|c|c|c|c|}
\hline Метод аналізу & Мета аналізу & Основні положення & $\begin{array}{c}\text { Проблеми під час } \\
\text { використання }\end{array}$ & Критика використання \\
\hline $\begin{array}{c}\text { Горизонтальний } \\
\underset{\text { (трендовий) }}{\text { аналіз }}\end{array}$ & $\begin{array}{c}\text { Вивчення } \\
\text { динаміки (основної } \\
\text { тенденції зміни) } \\
\text { загальної суми } \\
\text { адміністративних } \\
\text { витрат та окремих } \\
\text { їхніх складників у } \\
\text { часі }\end{array}$ & $\begin{array}{c}\text { Здійснюється } \\
\text { розрахунок темпів } \\
\text { зростання (приросту) } \\
\text { через порівняння } \\
\text { показників: звітного } \\
\text { періоду з показниками } \\
\text { попереднього; звітного } \\
\text { періоду з показниками } \\
\text { аналогічного періоду } \\
\text { попереднього; звітного } \\
\text { періоду з показниками } \\
\text { базового; за декілька } \\
\text { попередніх періодів }\end{array}$ & $\begin{array}{c}\text { Неврахування чинників } \\
\text { зовнішнього та } \\
\text { внутрішнього впливу } \\
\text { на величину загальної } \\
\text { суми адміністративних } \\
\text { витрат та окремих їхніх } \\
\text { складників, потужність } \\
\text { яких змінюється в часі } \\
\text { (напр., інфляційних } \\
\text { процесів, розвитку } \\
\text { інноваційних методів } \\
\text { управління) }\end{array}$ & $\begin{array}{c}\text { Динамічність } \\
\text { чинників зовнішнього } \\
\text { та внутрішнього } \\
\text { середовища } \\
\text { фунцціонування } \\
\text { підприємства знижує } \\
\text { цінність результатів } \\
\text { аналізу }\end{array}$ \\
\hline $\begin{array}{c}\text { Вертикальний } \\
\text { (структурний) } \\
\text { аналіз }\end{array}$ & $\begin{array}{c}\text { Встановлення } \\
\text { структури } \\
\text { адміністративних } \\
\text { витрат, а також } \\
\text { іх впливу на } \\
\text { фінансові результати } \\
\text { діяльності } \\
\text { підприємства }\end{array}$ & $\begin{array}{c}\text { Розраховується питома } \\
\text { вага окремих складників } \\
\text { адміністративних витрат, } \\
\text { а також частка останніх в } \\
\text { інших категоріях витрат } \\
\text { (непрямих, операційних, } \\
\text { загальних) }\end{array}$ & $\begin{array}{c}\text { Дискусійність необхідності } \\
\text { зіставлення показників, } \\
\text { які мають різну практичну } \\
\text { корисність та економічну } \\
\text { природу (скажімо, } \\
\text { витрат на оплату праці } \\
\text { управлінського персоналу } \\
\text { та коштів, затрачених на } \\
\text { придбання канцелярського } \\
\text { приладдя) } \\
\end{array}$ & $\begin{array}{c}\text { Цінність аналізу є } \\
\text { критично низькою } \\
\text { без використання } \\
\text { оптимальної моделі } \\
\text { структури витрат, } \\
\text { побудова якої є } \\
\text { важко вирішуваним } \\
\text { завданням }\end{array}$ \\
\hline $\begin{array}{c}\text { Кількісний } \\
\text { нормативний } \\
\text { аналіз }\end{array}$ & $\begin{array}{c}\text { Виявлення рівня } \\
\text { ефективності } \\
\text { використання } \\
\text { коштів на } \\
\text { управління } \\
\text { діяльністю } \\
\text { підприємства }\end{array}$ & $\begin{array}{c}\text { Порівняння показників } \\
\text { адміністративних } \\
\text { витрат з установленими } \\
\text { нормативними чи } \\
\text { запланованими } \\
\text { значеннями або } \\
\text { теоретично можливими } \\
\text { (оптимальною моделлю) }\end{array}$ & $\begin{array}{c}\text { Складність розроблення } \\
\text { моделі розвитку } \\
\text { підприємства, на основі } \\
\text { якої розраховуються точні } \\
\text { нормативні показники }\end{array}$ & $\begin{array}{c}\text { Ризики формування } \\
\text { недосяжних або, } \\
\text { навпаки, занижених } \\
\text { нормативних } \\
\text { показників діяльності }\end{array}$ \\
\hline $\begin{array}{c}\text { Галузевий } \\
\text { (просторовий) } \\
\text { аналіз }\end{array}$ & $\begin{array}{c}\text { Отримання } \\
\text { допоміжних даних } \\
\text { для встановлення } \\
\text { рівня конкуренто- } \\
\text { спроможності } \\
\text { підприємства }\end{array}$ & $\begin{array}{c}\text { Порівняння показників } \\
\text { адміністративних } \\
\text { витрат аналізованого } \\
\text { підприємства зі } \\
\text { спорідненими } \\
\text { підприємствами, } \\
\text { лідерами галузі чи } \\
\text { середньогалузевими } \\
\text { показниками } \\
\end{array}$ & $\begin{array}{c}\text { Важкість отримання } \\
\text { достовірної аналітичної } \\
\text { інформації в умовах } \\
\text { висококонкурентної } \\
\text { ринкової економіки }\end{array}$ & $\begin{array}{c}\text { Затрати на отримання } \\
\text { об’єктивної інформації } \\
\text { зазвичай перевищують } \\
\text { цінність отриманих } \\
\text { результатів аналізу }\end{array}$ \\
\hline $\begin{array}{c}\text { Факторний } \\
\text { аналіз }\end{array}$ & $\begin{array}{c}\text { Оцінка впливу } \\
\text { чинників на } \\
\text { формування } \\
\text { величини } \\
\text { адміністративних } \\
\text { витрат }\end{array}$ & $\begin{array}{c}\text { Здійснюється } \\
\text { виокремлення } \\
\text { складників показника } \\
\text { адміністративних } \\
\text { витрат із послідовним } \\
\text { розрахунком величини } \\
\text { впливу кожного з них } \\
\end{array}$ & $\begin{array}{c}\text { Можливість урахування } \\
\text { лише суто технічних } \\
\text { чинників, які піддаються } \\
\text { кількісній оцінці }\end{array}$ & \begin{tabular}{|c|} 
Чинники нефінансової \\
природи часто мають \\
найбільший вплив на \\
формування величини \\
адміністративних \\
витрат та їхню \\
структуру \\
\end{tabular} \\
\hline $\begin{array}{c}\text { Аналіз } \\
\text { коефіцієнтів }\end{array}$ & $\begin{array}{c}\text { Загальний аналіз } \\
\text { ефективності } \\
\text { вкладення } \\
\text { (рентабельності) } \\
\text { коштів у діяльність } \\
\text { підприємства }\end{array}$ & $\begin{array}{c}\text { Розрахунок коефіцієнтів, } \\
\text { в яких показники } \\
\text { адміністративних витрат } \\
\text { використовуються у } \\
\text { поєднанні з іншими } \\
\text { складниками витрат, а } \\
\text { також доходами }\end{array}$ & $\begin{array}{c}\text { Відсутність прямої } \\
\text { залежності між } \\
\text { джерелами формування } \\
\text { ресурсів та напрямами } \\
\text { їх використання (за } \\
\text { винятком коштів } \\
\text { цільового фінансування) } \\
\text { не дає можливості } \\
\text { встановлення ефективності } \\
\text { використання коштів на } \\
\text { адміністративні потреби } \\
\end{array}$ & $\begin{array}{c}\text { Неможливість } \\
\text { визначення } \\
\text { ефективності } \\
\text { формування прибутку } \\
\text { залежно від обсягів } \\
\text { адміністративних } \\
\text { витрат та ї структури } \\
\text { абстраговано від інших } \\
\text { показників, які на } \\
\text { нього впливають }\end{array}$ \\
\hline
\end{tabular}

використання інструментарію АВС-аналізу з виокремленням трьох груп адміністративних витрат:

група A - найбільш важливі для управління витрати, які мають «левову» частку у загальній сукупності адміністративних витрат підприємства. Статті таких витрат формують номенклатуру субрахунків до рахунку 92;

група В - середні за ступенем важливості витрати, які, однак, у перспективі можуть потрапити до групи А. Більшість зі статей таких витрат відносять до субрахунку «Інші адміністративні витрати», однак за рішенням головного бухгалтера по деяких усе ж можуть формуватися окремі субрахунки;

група C - несуттєві категорії адміністративних витрат, які становлять незначну частку в загальному підсумку, відповідно, найменше впливають на величину прибутку підприємства і представляють невеликий інтерес із погляду управління. Усі статті по таких витратах відносять до категорії «Інші адміністративні витрати».

Зазначимо, що параметром для ранжування (якщо ціллю для підприємства є оптимізація величини та структури витрат задля збільшення прибутковості діяльності) нами вибрано частку кожного виду адміністративних витрат в їх загальній сукупності. Розподіл за групами відбувається відповідно до внеску у загальний результат за цим параметром. Часовий інтервал даних для аналізу - останній звітний період (рік).

Існує достатньо багато методів поділу об'єктів аналізу на групи: емпіричний, суми, диференційований, багатокутника, дотичних, петлі. Їх практичне використання описано у низці джерел із 
теорії логістики [7]. На нашу думку, для потреб побудови аналітичного обліку адміністративних витрат цілком достатньо вибрати найбільш прості 3 них, наприклад емпіричний, який полягає у розподілі об'єктів на групи на основі усереднених результатів раніше проведених досліджень, чи метод суми, який передбачає виокремлення груп за сумою питомої ваги об'єктів у підсумку адміністративних витрат та їхнього внеску в загальний результат.

Проблемою інтерпретації результатів аналізу адміністративних витрат на останньому етапі є те, що дані асоціюються лише з числовим контентом звітних форм. Проте кількісні показники досить часто створюють лише ілюзію наявності повної та достовірної інформації для вирішення конкретної проблеми. Значно важливішим є віднаходження вдалого балансу між числовими показниками й якісними характеристиками, які враховують максимальну кількість чинників впливу зовнішнього та внутрішнього середовища на величину, структуру i тенденції зміни адміністративних витрат. Окрім того, критично важливим є належне делегування повноважень, за якого на кожному рівні управління приймаються рішення на основі аналітичних даних різного рівня агрегування.
Висновки і пропозиції. За результатами проведеного дослідження пропонуємо:

1) застосовувати в обліку перелік адміністративних витрат шляхом їх вибору з пропонованих типових субрахунків: 921 «Матеріальні адміністративні витрати»; 922 «Витрати на оплату праці адміністративно-управлінського та іншого загальногосподарського персоналу»; 923 «Відрахування на соціальні заходи в частині адміністративних витрат»; 924 «Амортизація необоротних активів загальногосподарського призначення»; 925 «Витрати, пов'язані з отриманням банківських послуг»; 926 «Витрати, пов’язані з отриманням послуг інших сторонніх організацій»; 927 «Операційні податки»; 928 «Інші адміністративні витрати»;

2) для визначення конкретного переліку адміністративних витрат, який варто виокремлювати в аналітичному обліку, необхідно щороку здійснювати їх ранжування за параметром значимості для підприємства з використанням інструментарію АВС-аналізу;

3) розширити спектр методичних прийомів у практиці аналізу адміністративних витрат за рахунок зміщення пріоритетів на користь застосування якісних методів діагностики.

\section{Список використаних джерел:}

1. Купалова Г.І. Теорія економічного аналізу : навчальний посібник. Київ, 2008. 639 с.

2. Попович П.Я. Економічний аналіз діяльності суб'єктів господарювання : підручник. Київ, 2008.630 с.

3. Дворянкина А.А., Рогуленко Т.М. Развитие, цели, задачи и сущность комплексного экономического анализа деятельности предприятий. Эконолика: проблелы, решения и перспективы. 2017. № 10. С. 67-73.

4. Організація і методика економічного аналізу : навчальний посібник / Т.Д. Косова та ін. Київ, 2012. 528 с.

5. Економічний аналіз : навчальний посібник / М.А. Болюх та ін. ; вид. 2-е, перероб. і доп. Київ, 2003.556 с.

6. Стецюк Л.С. Організація аналітичної роботи на сільськогосподарських підприємствах. URL : http://magazine.faaf. org.ua/organizaciya-analitichnoi-roboti-na-silskogospodarskih-pidpriemstvah.html (дата звернення: 22.11.2019).

7. Модели и методы теории логистики : учебнок пособие / под ред. В.С. Лукинского ; 2-е изд. Санкт-Петербург : Питер, 2008. $448 \mathrm{c}$

\section{References:}

1. Kupalova Gh. I. (2008) Teorija ekonomichnogho analizu [The theory of economic analysis]: navchaljnyj posibnyk. Kyjiv.

2. Popovych P. Ja. (2008) Ekonomichnyj analiz dijaljnosti sub'jektiv ghospodarjuvannja [Economic analysis of business entities]: pidruchnyk. Kyjiv. 630s.

3. Dvoryankina A. A., Rogulenko T. M. (2017) Razvitie, tseli, zadachi i suschnost kompleksnogo ekonomicheskogo analiza deyatelnosti predpriyatiy [Development, goals, objectives and essence of a comprehensive economic analysis of enterprises]. Ekonomika: problemyi, resheniya i perspektivyi. no. 10, pp. 67-73.

4. Kosova T. D., Sukharev P. M., Vashhenko L. O. (2012) Orghanizacija i metodyka ekonomichnogho analizu [Organization and methodology of economic analysis]. Kyjiv.

5. Boljukh M. A., Burchevsjkyj V. Z., Ghorbatjuk M. I. ta in. (2003). Ekonomichnyj analiz [Economic analysis]: navch. posibnyk. Vyd. 2-ghe, pererob. i dop. Kyjiv.

6. Stecjuk L. S. Orghanizacija analitychnoji roboty na siljsjkoghospodarsjkykh pidpryjemstvakh [Organization of analytical work at agricultural enterprises]. Avaialable at: http://magazine.faaf.org.ua/organizaciya-analitichnoi-roboti-na-silskogospodarskih-pidpriemstvah.html (accessed 22 November 2019).

7. Lukinskii V. S. (ed.)(2008) Modeli i metodyi teorii logistiki [Models and methods of logistics theory]. Sankt-Peterburg: Piter. (in Russian) 
Височан О. С.

Литвиненко Н. А.

Национальный университет «Львовская политехника»

\title{
ПРОБАЕМАТИКА АНААИТИЧЕСКОЙ ОБРАБОТКИ УЧЕТНЫХ ААННЫХ ПО ААМИНИСТРАТИВНЫМ РАСХОААМ ПРЕАПРИЯТИЯ
}

\section{Резюме}

Исследована потенциальная возможность повышения полезности аналитического учета как основы для роста эффективности анализа административных расходов в управлении финансово-хозяйственной деятельностью предприятия. Осуществлена критическая оценка установления критерия минимизации как основной цели управления административными затратами на предприятии. Проведено структурирование задач анализа административных расходов. Выделены проблемы, возникающие при применении классических приемов для анализа административных расходов предприятия, а также установлены возможные негативные последствия такого применения на практике. Предложена номенклатура субсчетов к счету бухгалтерского учета "Административные расходы». Установлена возможность применения технологии АВС-анализа для построения аналитического учета затрат.

Ключевые слова: административные расходы, косвенные расходы, АВС-анализ, аналитический учет, субсчет.

\author{
Vysochan Oleh \\ Lytvynenko Nataliya \\ Lviv Polytechnic National University
}

\section{PROBLEMATICS OF ANALYTICAL PROCESSING OF ACCOUNTING DATA ABOUT THE ADMINISTRATIVE EXPENSES OF ENTERPRISE}

\section{Summary}

The potential of increasing the usefulness of analytical accounting as a basis for increasing the efficiency of the analysis of administrative expenses in managing the financial and economic activity of the enterprise has been investigated. Critical assessment of establishing the criterion of minimization as the main purpose of managing administrative expenses at the enterprise to reduce: expenses on the maintenance of fixed assets, other tangible fixed assets of general economic use; personnel costs; expenses on business trips of managers of the enterprise; costs for the services of third parties; total corporate expenses; tax burden. Potential threats to the management of administrative costs have been identified based on the minimization criterion. The tasks of the analysis of administrative expenses are structured: identification of the most cost-intensive units in ensuring the general economic activity of the enterprise; providing analytical information to the subsystem for monitoring the efficiency of use of resources for general economic needs; substantiation of necessity of increase / decrease of financing of general economic needs; creation of conditions for personification of responsibility for increase of unproductive losses of administrative and managerial character. The problems that arise when applying the classical methods for the analysis of the administrative expenses of the enterprise are highlighted, as well as the possible negative consequences of such application in practice. The nomenclature of subaccounts to the account "Administrative expenses" is proposed: 921 "Material administrative expenses"; 922 "Wages and salaries of administrative, management and other general staff"; 923 "Deductions for social activities in terms of administrative expenses"; 924 "Depreciation of non-current assets of general purpose"; 925 "Expenses related to obtaining banking services"; 926 "Costs related to getting third party services"; 927 "Operating taxes"; 928 "Other administrative expenses". The possibility of using ABC-analysis technology to build an analytical accounting of administrative costs has been established. Keywords: administrative expenses, indirect costs, ABC-analysis, analytical accounting, subaccount. 